\title{
In situ Reduction and Oxidation of Nickel from Solid Oxide Fuel Cells in a Transmission Electron Microscope
}

Faes, Antonin; Jeangros, Quentin; Wagner, Jakob Birkedal; Hansen, Thomas Willum; Van Herle, Jan; Brisse, Annabelle; Dunin-Borkowski, Rafal E.; Hessler-Wyser, Aïcha

\author{
Published in: \\ E C S Transactions \\ Link to article, DOI: \\ 10.1149/1.3205743 \\ Publication date: \\ 2009
}

Document Version

Publisher's PDF, also known as Version of record

Link back to DTU Orbit

Citation (APA):

Faes, A., Jeangros, Q., Wagner, J. B., Hansen, T. W., Van Herle, J., Brisse, A., Dunin-Borkowski, R. E., \& Hessler-Wyser, A. (2009). In situ Reduction and Oxidation of Nickel from Solid Oxide Fuel Cells in a

Transmission Electron Microscope. E C S Transactions, 25(2), 1985-1992. https://doi.org/10.1149/1.3205743

\section{General rights}

Copyright and moral rights for the publications made accessible in the public portal are retained by the authors and/or other copyright owners and it is a condition of accessing publications that users recognise and abide by the legal requirements associated with these rights.

- Users may download and print one copy of any publication from the public portal for the purpose of private study or research.

- You may not further distribute the material or use it for any profit-making activity or commercial gain

- You may freely distribute the URL identifying the publication in the public portal 


\title{
In situ Reduction and Oxidation of Nickel from Solid Oxide Fuel Cells in a Transmission Electron Microscope
}

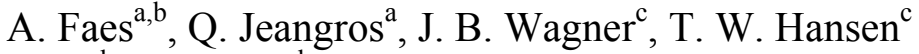 \\ J. Van herle ${ }^{\mathrm{b}}$, A. Brisse ${ }^{\mathrm{d}}$, R. Dunin-Borkowski ${ }^{\mathrm{c}}$, A. Hessler-Wyser ${ }^{\mathrm{a}}$ \\ ${ }^{a}$ Interdisciplinary Centre for Electron Microscopy \\ Ecole Polytechnique Fédérale de Lausanne (EPFL), CH-1015 Lausanne, Switzerland \\ ${ }^{\mathrm{b}}$ Laboratory of Industrial Energy Systems, EPFL, CH-1015 Lausanne, Switzerland \\ ${ }^{\mathrm{c}}$ Center for Electron Nanoscopy \\ Technical University of Denmark, DK-2800 Lyngby, Denmark \\ ${ }^{\mathrm{d}}$ European Institute for Energy Research \\ Emmy-Noether-Strasse 11, Karlsruhe, Germany
}

Environmental transmission electron microscopy was used to characterize in situ the reduction and oxidation of nickel from a $\mathrm{Ni} / Y S Z$ solid oxide fuel cell anode support between $300-500^{\circ} \mathrm{C}$. The reduction is done under low hydrogen pressure. The reduction initiates at the $\mathrm{NiO} / \mathrm{YSZ}$ interface, then moves to the center of the $\mathrm{NiO}$ grain. At higher temperature the reduction occurs also at the free $\mathrm{NiO}$ surface and the $\mathrm{NiO} / \mathrm{NiO}$ grain boundaries. The growth of $\mathrm{Ni}$ is epitaxial on its oxide. Due to high volume decrease, nanopores are formed during reduction. During oxidation, oxide nanocrystallites are formed on the nickel surface. The crystallites fill up the nickel porosity and create an inhomogeneous structure with remaining voids. This change in structure causes the nickel oxide to expand during a RedOx cycle.

\section{Introduction}

Solid oxide fuel cells (SOFC) are efficient devices for the electrochemical conversion of a large variety of fuels into electricity (1). The standard SOFC design is based on an electrolyte-supporting anode composed of yttria stabilized zirconia (YSZ) and nickel oxide (NiO). $\mathrm{NiO}$ is reduced in situ into metallic nickel during the first use of the fuel cell. This reaction increases the anode porosity due to volume contraction between $\mathrm{NiO}$ and $\mathrm{Ni}$, induces high electrical conductivity of the support and sufficient electrochemical activity of the anode due to high nickel activity for $\mathrm{H}_{2}$ oxidation. The reduction procedure is important as it can influence the anode support conductivity (2) and strength (3).

Oxidation of the nickel phase can occur during SOFC stack operation due to air leakage through the sealing, lack of fuel, high fuel utilization, or a shut down without protection gas. The important expansion during oxidation produces stress in the YSZ backbone and may lead to the formation of cracks in the thin electrolyte (4-7). The reason why reoxidized nickel does not occupy the same volume as in the original structure is controversially presented in the literature. The first approach proposes the coarsening of the nickel phase during fuel cell utilization at high temperature $\left(700\right.$ to $\left.900^{\circ} \mathrm{C}\right)$ as the main reason of the detrimental effect of nickel reoxidation $(8,9)$. Others indicated a 
porosity in nickel oxide after reoxidation due to the outward diffusion of $\mathrm{Ni}$ trough $\mathrm{NiO}$ (10), the size and volume of porosity being influenced by the cermet reoxidation temperature (7). As some groups demonstrate expansion of the anode support after consecutive RedOx cycles (without the nickel coarsening step) $(6,7)$, the first hypothesis can not be self-sufficient.

In situ characterization can yield interesting observations during the reaction, like crystallographic changes using time resolved X-ray diffraction (TRXRD) (11) and high energy TRXRD using a synchrotron source (12). In situ microstructural changes have been observed using an environmental scanning electron microscope (ESEM) (13). This study showed a shrinkage of the Ni phase during $\mathrm{NiO}$ reduction. The microstructure of the $\mathrm{NiO}$ depended on the temperature of reoxidation; at low temperature the particles stay spherical but at higher temperature the original $\mathrm{Ni}$ particles separate into different $\mathrm{NiO}$ grains. In situ environmental transmission electron microscopy (ETEM) used in the present work can give information on micro and nanostructures as well as local composition and crystallographic analysis. Time resolved ETEM observation is a powerful tool to understand the reaction processes during reduction and oxidation in the electro-catalytic field.

\section{Experimental}

The observed sample is a standard anode supported thin electrolyte from HTceramix $\mathrm{SA}^{\circledR}$ (Switzerland). This sample was fabricated by co-casting electrolyte $(4-5 \mu \mathrm{m})$ and anode (about $200 \mu \mathrm{m}$ ) tapes. The anode is composed of nickel oxide and YSZ and the electrolyte is dense 8YSZ. A TEM lamella of the NiO-YSZ anode was extracted in situ from the sample using a lift-out technique with a FEI Quanta ${ }^{\mathrm{TM}}$ dual beam SEM/focused ion beam (FIB) equipped with a micromanipulator. The lamella was glued on a stainless steel grid with platinum deposition. Thinning down of the TEM sample to $80 \mathrm{~nm}$ was achieved with a FEI Helios $^{\text {TM }}$ dual beam SEM/FIB.

TEM in situ observations were done in a FEI $\operatorname{Titan}^{\mathrm{TM}}$ equipped with an environmental cell (E-cell). This microscope is operated at $300 \mathrm{kV}$ with a field emission gun and is equipped with a monochromator and Cs image aberration corrector. EDX detector and a Gatan Image filter are used for analytical characterization. The in situ reduction was done in $1.4 \mathrm{mbar}_{2}$. The temperature was ramped between $300^{\circ} \mathrm{C}$ and $500^{\circ} \mathrm{C}$ with a $10^{\circ} \mathrm{C}$ increment every $5 \mathrm{~min}$. The oxidation was done in $3.2 \mathrm{mbar}_{2}$ from $250^{\circ} \mathrm{C}$ to $500^{\circ} \mathrm{C}$ using the same temperature ramp as for the reduction.

\section{Results and Discussion}

\section{$\underline{\text { Reduction }}$}

Some characteristic images acquired during the in situ reduction of the composite anode are shown in Figure 1. The reduction of $\mathrm{NiO}$ starts at around $320^{\circ} \mathrm{C}$ as indicated by the arrow in Figure 1c. The texture of the grain boundary from Figure 1a to Figure 1c varies a little (the texture of the interface changes due to porosity apparition). This can be seen in a clearer way in Figure 1d. From 410 to $430^{\circ} \mathrm{C}$, the reduction of $\mathrm{NiO}$ takes place 

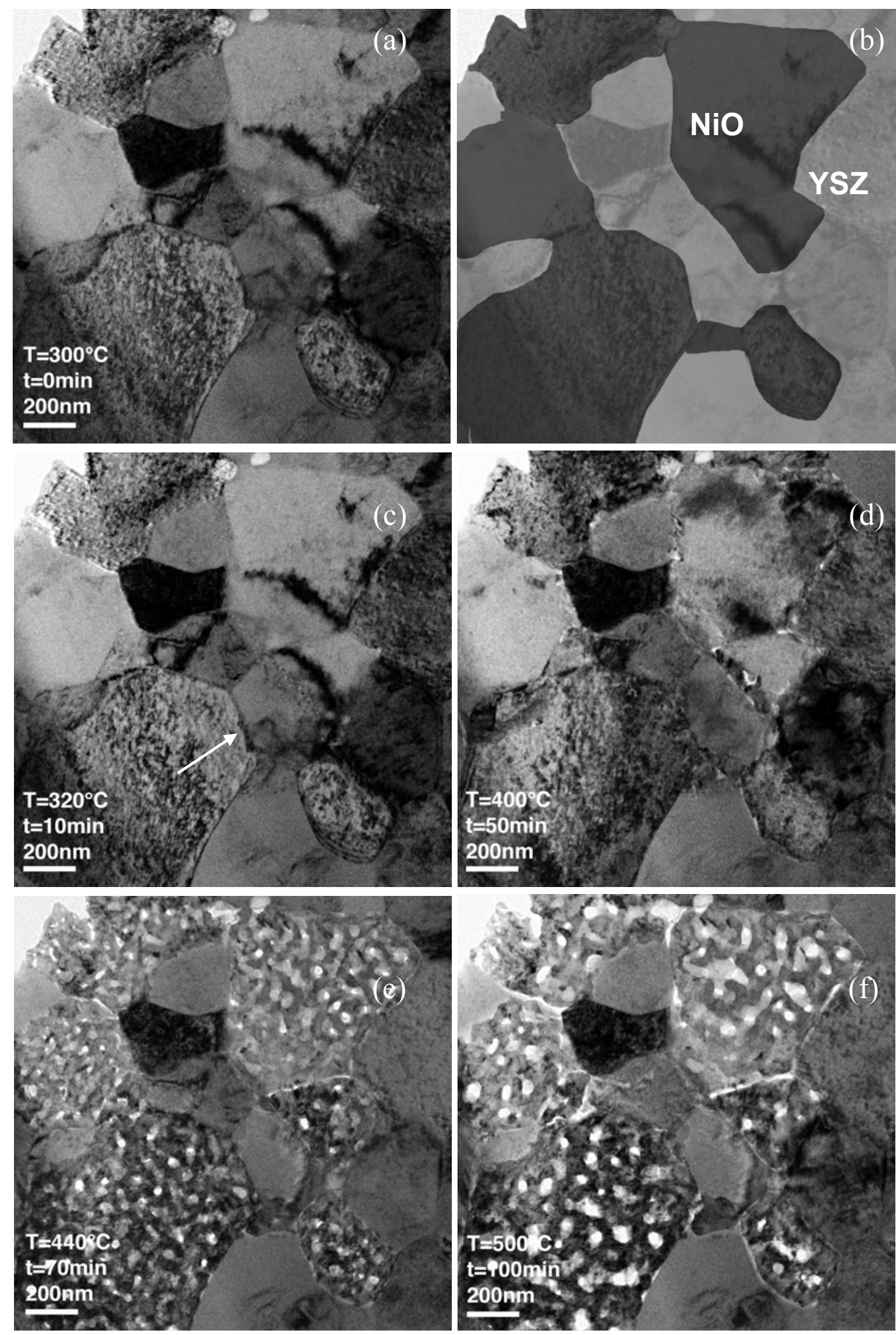

Figure 1. Sequence of bright field micrographs of the YSZ/NiO composite reduction under 1.4 mbar $\mathrm{H}_{2}$ with plateaus of 5 min. every $10^{\circ} \mathrm{C}$, (a) As prepared sample at $300^{\circ} \mathrm{C}$, (b) map of $\mathrm{NiO}$ (dark grey) and YSZ (light grey) phases as a visual indication, (c) $320^{\circ} \mathrm{C}$, (d) $400^{\circ} \mathrm{C}$, (e) $440^{\circ} \mathrm{C}$ and (f) $500^{\circ} \mathrm{C}$. 
also directly on the free surface. The reduction of nickel oxide to metallic nickel leaves a nanoporosity due to the volume contraction of more than $40 \%$ (7). Such nanoporosities were observed by Waldbillig et al. in ex situ reduction of a TEM lamella (14). The porous nanostructure further evolves under the microscope between $440^{\circ} \mathrm{C}$ and $500^{\circ} \mathrm{C}$ (Figure $1 \mathrm{e}$ and $\mathrm{f}$ ). This can be due to nickel coarsening but also to the continuation of reduction of remaining $\mathrm{NiO}$.

It is interesting to note that the reduction starts from the YSZ/NiO interface. Figure $1 \mathrm{~b}$ shows a superimposed map of $\mathrm{NiO}$ (dark grey) and YSZ (light grey) phases on the bright field image (this map is an indication to distinguish the different phase grains). The $\mathrm{NiO} / \mathrm{NiO}$ grain boundaries are reduced only later, when the reduction also takes place on the free surface. Diffraction patterns (DP) were obtained during reduction, as presented in Figure 2. Ni grows epitaxially on the nickel oxide, shown by the satellite spots of Figure $2 \mathrm{~b}$ (14). These satellite spots are due to double diffraction by metallic nickel and nickel oxide. Both nickel and nickel oxide are cubic but with different lattice parameters $\left(\mathrm{d}_{\mathrm{Ni}, 111}=0.204 \mathrm{~nm}\right.$ and $\left.\mathrm{d}_{\mathrm{NiO}, 111}=0.241 \mathrm{~nm}(15)\right)$. The DP of not fully reduced nickel oxide leads to small satellite spots. When the reduction is completed, NiO satellite spots on the DP are absent.
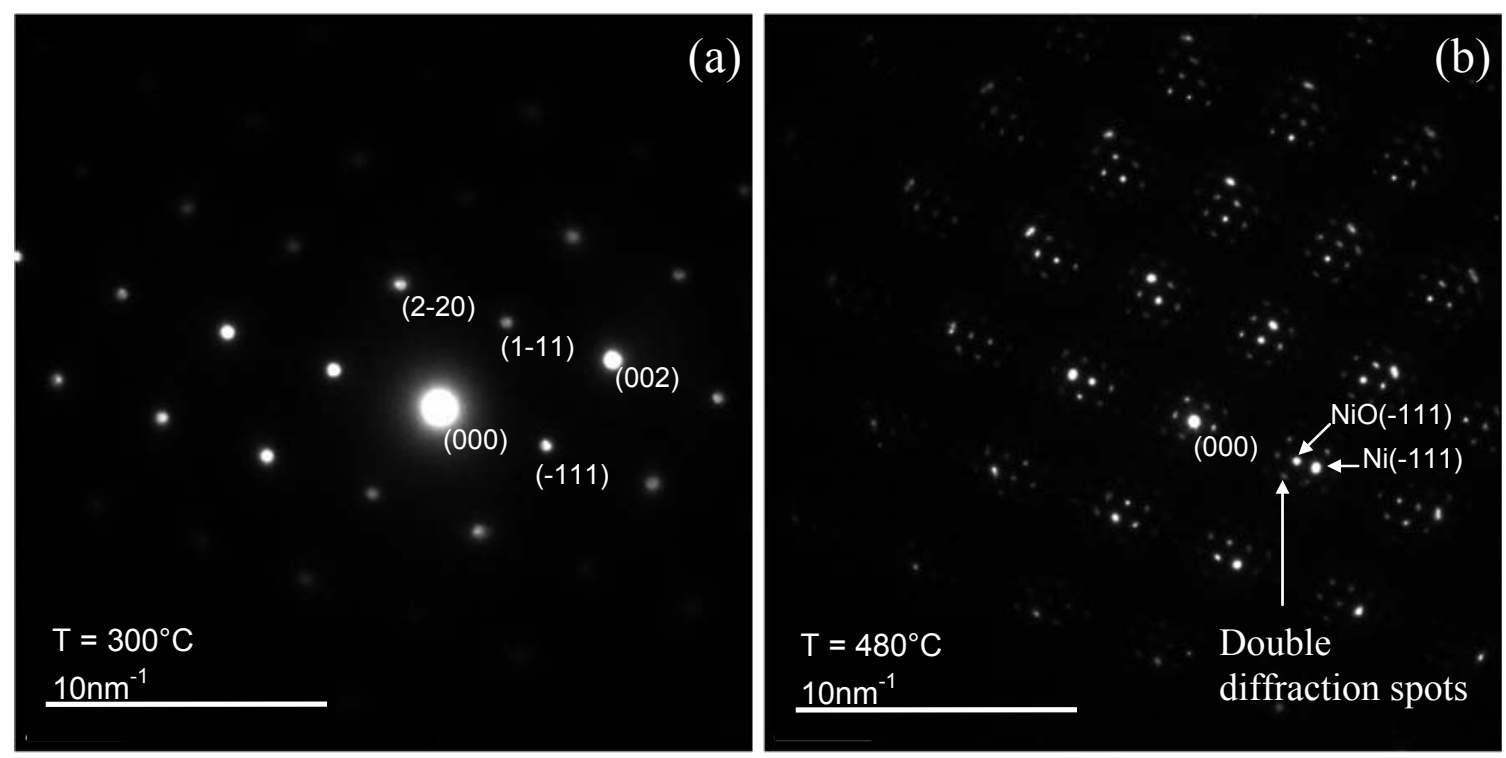

Figure 2. Diffraction pattern from a $\mathrm{NiO}$ grain in [110] zone axis during reduction under $1.4 \mathrm{mbar}_{2}$, (a) at $300^{\circ} \mathrm{C}$ and (b) $480^{\circ} \mathrm{C}$.

Figure 3 schematizes the process of $\mathrm{NiO}$ reduction of a $\mathrm{YSZ} / \mathrm{NiO}$ grain interface (view of the cross section or thickness of a TEM lamella). Up to $300^{\circ} \mathrm{C}$, the nickel oxide is stable. Then the reduction process initiates at the YSZ interface from where it proceeds to the center of the grain. The adsorption of hydrogen may be energetically more favorable on stabilized zirconia than on defect free NiO. YSZ can act as a transmitter of hydrogen active species (16). As the reduction is autocatalytic the reaction proceeds to the center of the $\mathrm{NiO}$ grain. Above $410^{\circ} \mathrm{C}$ onwards, the reduction occurs also at the free surface of nickel oxide. During the reduction process, the nanopores size increases due to the continuous volume contraction. Even at $480^{\circ} \mathrm{C}$, some nickel oxide remains, as shown by the satellite spot in the DP (Figure $2 \mathrm{~b}$ ). At $500^{\circ} \mathrm{C}$, some of the pores combine to transverse channels through the TEM lamella. Gaseous transport during reduction may 
then occur through such nanochannels, which drastically increase the tortuosity of the support.

After reduction at these conditions, only little contraction of the grains is observed; the volume decrease is principally compensated by formation of nanoporosities. Generally, a small porosity appears at the interface of two different nickel grains. As the gap is small, electrical conductivity should remain sufficient. If these nickel nanopores coalesce at higher temperature, the gap may increase and cause the anode electrical conductivity to drop.

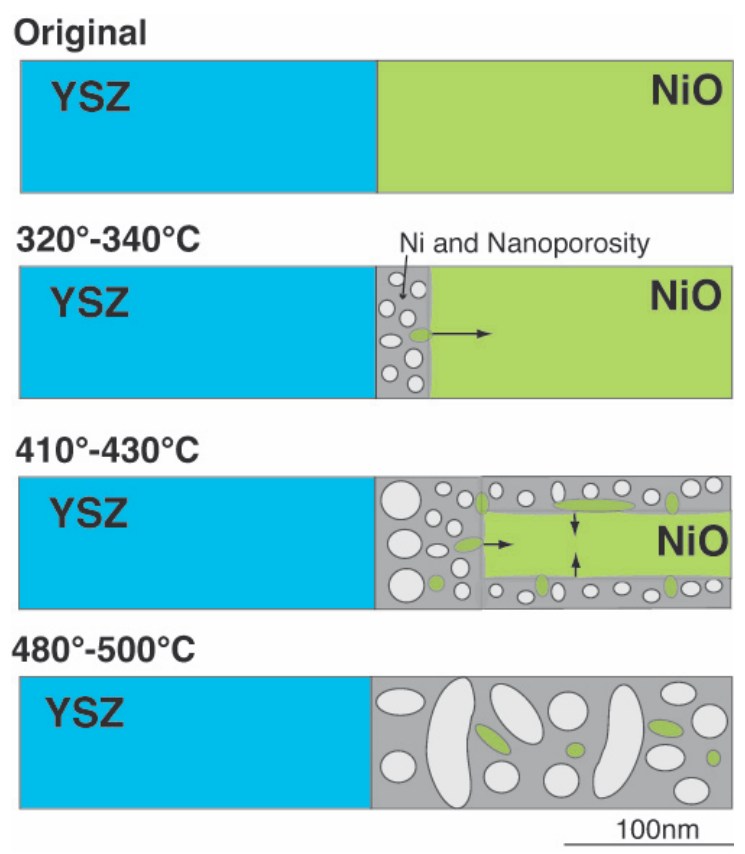

Figure 3. YSZ/NiO interface during reduction of $\mathrm{NiO}$ (presented as a cross section view of the TEM lamella). Between $320^{\circ} \mathrm{C}$ and $340^{\circ} \mathrm{C}$ the reduction of $\mathrm{NiO}$ starts at the interface and leaves nanoporosities in the nickel. Between 410 and $430^{\circ} \mathrm{C}$ the reduction also starts on the free $\mathrm{NiO}$ surface. Nickel oxide remains up to $480^{\circ} \mathrm{C}$ (as shown by satellite spots in DF of Figure 2b). The nickel nanostructure coarsens until $500^{\circ} \mathrm{C}$.

\section{$\underline{\text { Oxidation }}$}

In Figure 4, the in situ reoxidation of the anode is shown. Only a small selection of bright field images is presented. Microstructural changes start to be visible at around $350^{\circ} \mathrm{C}$ during in situ nickel reoxidation. The oxide grows at the nickel surface and the nanoporosity slowly closes back (see sequence in Figure 4). The nickel oxide grows as polynanocrystallites (small black dots in bright field shown by the arrows in Figure $5 \mathrm{~b}$ ). Ex situ re-oxidation of a TEM lamella also showed polycrystalline nickel oxide (14). The texture of nickel oxide grains is not homogeneous and seems to contain remaining porosity. This remaining porosity causes nickel oxide to expand during a reduction and oxidation (RedOx) cycle. This is well demonstrated in Figure 5. The two NiO grains adjacent to the pore expand into it showing the volume increase of the NiO phase during the RedOx cycle. The nickel oxide surface after oxidation (shown by the circle in Figure 5 b) is hilly and serrated, which could be due to the polycrystalline structure and shows 
the rugged nanostructure of a $\mathrm{NiO}$ grain after a RedOx cycle compared to its smooth original. This is another reason for expansion of nickel oxide during RedOx cycling.
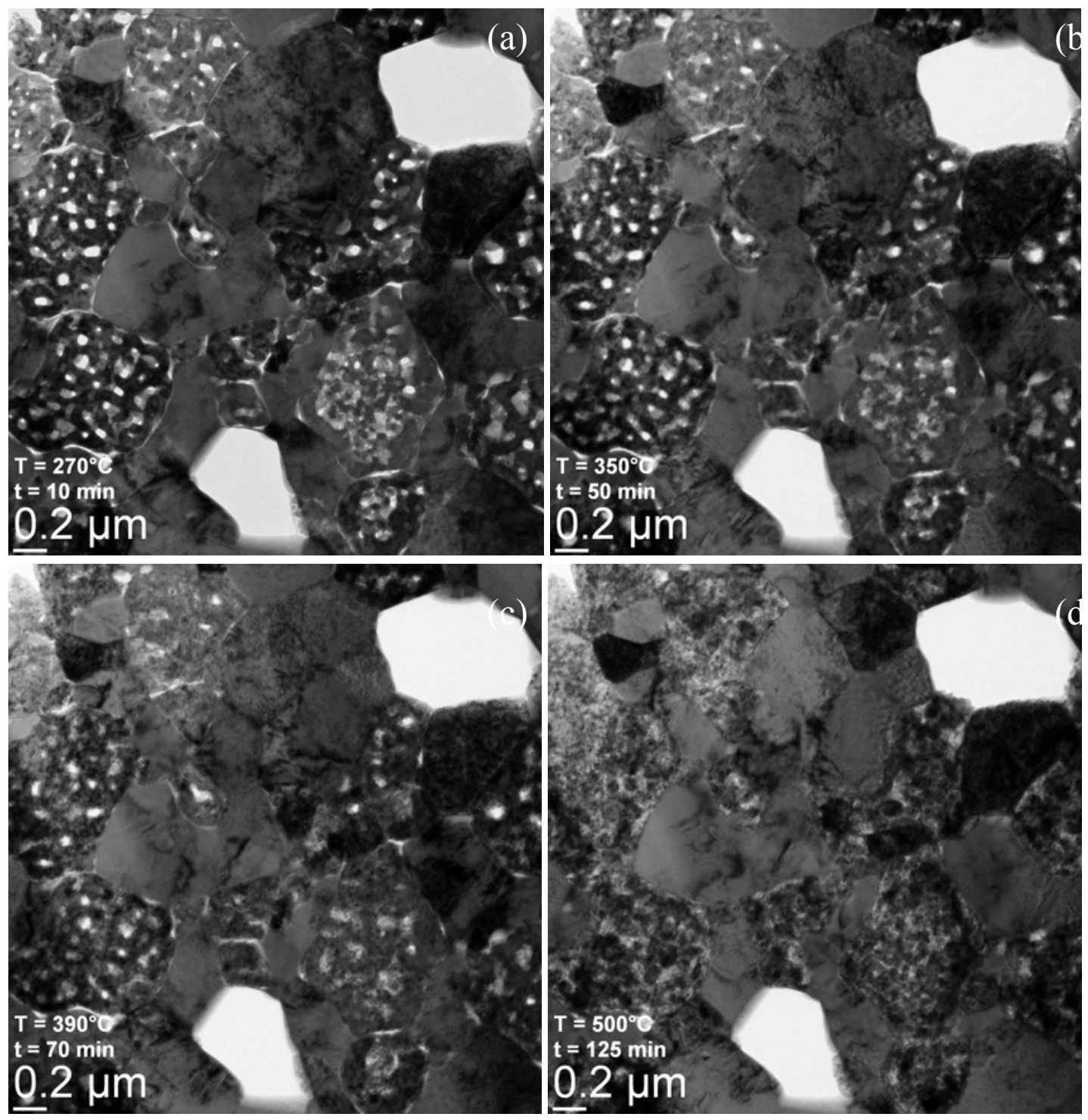

Figure 4. Sequence of bright field micrographs of the YSZ/Ni composite oxidation under 3.2 mbar $\mathrm{O}_{2}$ with plateaus of 5 min. every $10^{\circ} \mathrm{C}$ (a) sample at $270^{\circ} \mathrm{C}$, (b) $350^{\circ} \mathrm{C}$, (c) $390^{\circ} \mathrm{C}$ and $(\mathrm{d}) 500^{\circ} \mathrm{C}$.

Nickel oxide reorganization demonstrates the irreversibility of a RedOx cycle on the SOFC anode microstructure. As the $\mathrm{NiO}$ nanocrystallites rearrangement is slow at those temperatures, the YSZ backbone can withstand the tensile stress, but in case of reoxidation at higher temperature the reaction is so fast that no nanocrystallite rearrangement and no stress accommodation can occur. As a final remark, it is important to note that the TEM lamella thickness $(100 \mathrm{~nm})$ is about 100 times smaller than its width. The TEM sample can therefore differ in some points from a bulk anode material as it exposes more free surface and the $\mathrm{NiO}$ growth can be out of the lamella plane. 

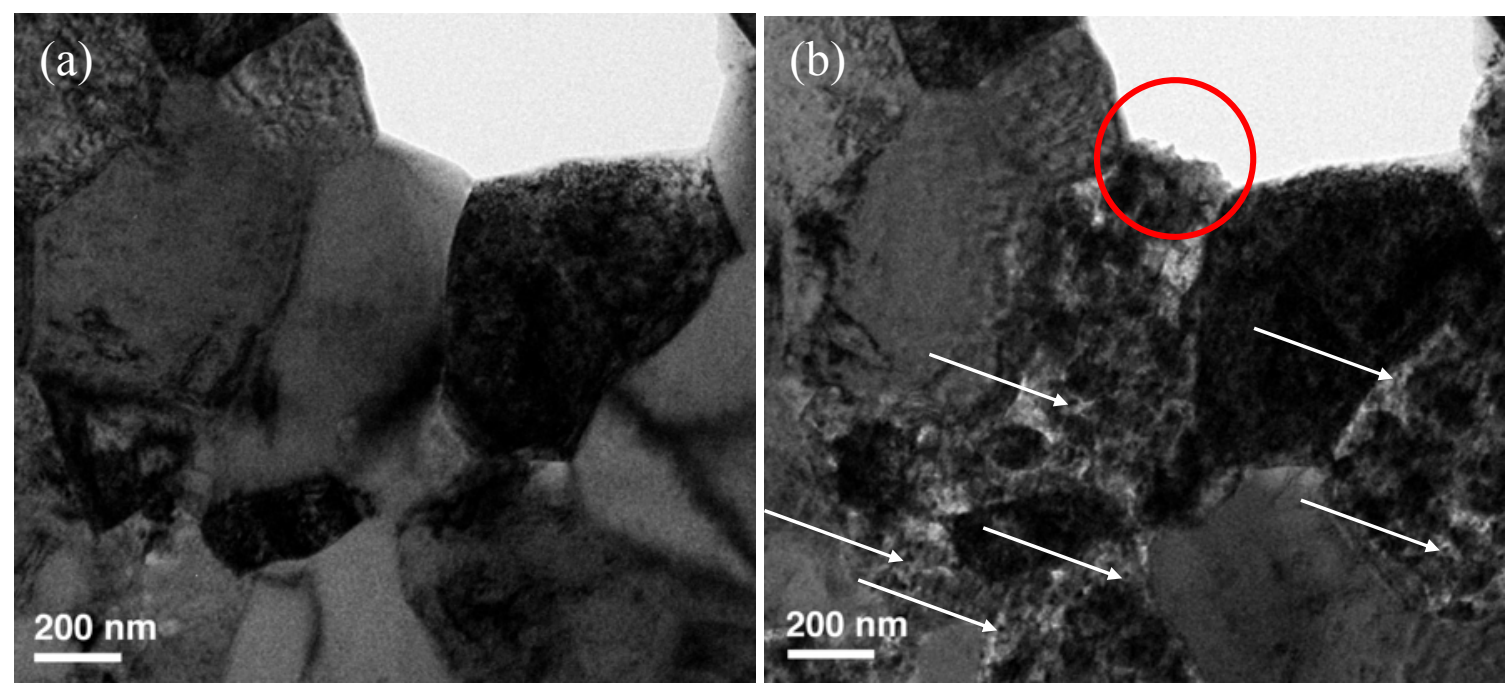

Figure 5. Bright field micrographs of the same location (a) before and (b) after in situ reduction and oxidation (RedOx) cycle. Arrows indicate $\mathrm{NiO}$ nanoparticles. The circle indicates the $\mathrm{NiO}$ expansion inside the porosity.

\section{Conclusions}

Environmental transmission electron microscopy was used to characterize in situ the reduction and re-oxidation of nickel from a Ni/yttria stabilized zirconia solid oxide fuel cell anode support. Reduction of nickel oxide initiates at the NiO/YSZ interfaces at around $320^{\circ} \mathrm{C}$ and proceeds then to the center of the grain as it is autocatalytic. Reduction on the free $\mathrm{NiO}$ surface and at the $\mathrm{NiO} / \mathrm{NiO}$ grain boundaries occurs from around $410^{\circ} \mathrm{C}$. Nickel grows epitaxially on its oxide. Nanostructured porosity is created during reduction due to the high volume decrease between nickel oxide and metallic nickel ( $>40 \mathrm{vol} \%)$.

Oxidation of nickel produces oxide nanocrystallites. As the nanoporosity is refilled with crystallites, a large amount of porosity is trapped inside the reoxidized structure. To compensate the volume expansion, nickel oxide consequently has to expand in the original pores and out of the lamella plane. The voids are contributing to the total volume during reoxidation leading to the instability of the anode microstructure during RedOx cycles. This phenomenon explains the irreversibility of a RedOx cycle for Ni/YSZ SOFC anode microstructure.

\section{Acknowledgments}

Kind acknowledgements are extended to HTceramix ${ }^{\circledR}$ SA (Switzerland) for material supply.

\section{References}

1. S. C. Singhal and K. Kendall, High Temperature Solid Oxide Fuel Cell Fundamentals, Design and Applications, p. 15, Elsevier, Oxford (2003). 
2. L. Grahl-Madsen, P. H. Larsen, N. Bonanos, J. Engell, and S. Linderoth, J. Mater. Sci., 41, 1097 (2006).

3. A. Faes, H. Lund-Frandsen, M. Pihlatie, A. Kaiser, and D. R. Goldstein, J. Fuel Cell Sci. Tech., Accepted (2009).

4. M. Cassidy, G. Lindsay, and K. Kendall, J. Power Sources, 61, 189 (1996).

5. D. Sarantaridis, and A. Atkinson, Fuel Cells, 7, 246 (2007).

6. M. Pihlatie, A. Kaiser, P. H. Larsen, and M. Mogensen, ECS Trans., 7, 1501 (2007).

7. A. Faes, A. Nakajo, A. Hessler-Wyser, D. Dubois, S. Modena, A. Brisse, and J. Van herle, J. Power Sources, In Press, (2009), DOI: 10.1016/j.jpowsour.2008.12.118.

8. T. Klemensoe, Relationships between structure and performance of SOFC anodes, $\mathrm{PhD}$ thesis, Technical University of Danemark, Risoe National Laboratory, p. 30, Roskilde (2005).

9. T. Klemensoe and M. Mogensen, J. Am. Ceram. Soc., 90, 3582 (2007).

10.D. Sarantaridis, R. J. Chater and A. Atkinson, J. Electrochem. Soc., 155, B467 (2008).

11. A. R. Rojas, H. E. Esparza-Ponce, L. Fuentes, A. Lopez-Ortiz, A. Keer and J. ReyesGasga, J. Phys. D: Appl. Phys., 38, 2276 (2005).

12. A. Hagen, H. F. Poulsen, T. Klemensoe, R. V. Martins, V. Honkimki, T. Buslaps and R. Feidenshans, Fuel Cells, 6, 361 (2006).

13. T. Klemensoe, C. C. Appel and M. Mogensen, Electrochem. Solid-State Lett., 9, 403 (2006).

14. D. Waldbillig, A. Wood and D. G. Ivey, J. Power Sources, 145, 206 (2005).

15. E. C. Dickey, V. P. Dravid, P. D. Nellist, D. J. Wallis, S. J. Pennycook and A. Revcolevschi, Microsc. Microanal., 3, 443 (1997).

16. M. Pospisil and P. Kanokova, J. Therm. Anal. Calorim., 58, 77 (1999). 